\title{
Effect of Simvastatin on Immune Cells under Alkaline and Acidic Conditions
} Toshihiko Fukamachi, Hiromi Saito and Hiroshi Kobayashi*

Graduate School of Pharmaceutical Sciences, Chiba University, Chiba 260-8675, Japan

\begin{abstract}
Many clinical investigations have suggested that statins are useful chemotherapeutics against various cancers, whereas in vitro experiments using cancer cell lines have shown little effect of statins on cell proliferation and survival. Our group previously demonstrated that statins were preferentially cytotoxic against HeLa, mesothelioma, and pancreatic tumor cells under acidic conditions. A serious side effect of anti-cancer drugs used now is the impairment of the immune system. In this study, we examined the effect of simvastatin on the immune cell lines THP-1 and Jurkat in alkaline and acidic media. Our data suggest that simvastatin inhibited proliferation, survival, and cytokine production at an acidic $\mathrm{pH}$ in these cells, whereas the inhibitory effect was negligible at an alkaline $\mathrm{pH}$. These results suggest that anti-cancer drugs whose efficacy increases in acidic cancer nests are useful for potent chemotherapeutics against cancer without causing serious damage to the immune cells in blood and normal tissues, whose $\mathrm{pH}$ is slightly alkaline, although the functions of immune cells that have infiltrated acidic cancer nests may be attenuated.
\end{abstract}

Keywords: Anti-cancer drugs; Statins; Immune cells; Acidic pH; Microenvironment

\section{Introduction}

In mammals, blood and normal tissues are maintained within a narrow $\mathrm{pH}$ range around 7.4, mainly through the regulation of respiration and renal acid extrusion [1,2]. The extracellular $\mathrm{pH}$, however, decreases to a value below 6 due to the destruction of blood vessels in cancer nests, resulting in the enhancement of hypoxic metabolism that produces lactic acid [3]. It has been reported that cancer nests are acidified by lactic acid accumulation, which is caused by the enhancement of glycolysis combined with impaired mitochondrial oxidative phosphorylation, even if the oxygen supply is not impaired [4].

The $\mathrm{pH}$ alteration in cancer nests affects cellular metabolic pathways because all enzyme activities are dependent on the $\mathrm{pH}$. The acidification of cancer nests may affect the functions of target molecules of anti-cancer drugs. Our group previously found that the inhibitory efficacy of statins, manumycin $\mathrm{A}$, and cantharidin increases at an acidic $\mathrm{pH}[5,6]$. Statins are a competitive inhibitor of HMG-CoA reductase, the rate-limiting enzyme for the biosynthesis of cholesterol and higher isoprenoids, such as farnesyldiphosphate and geranylgeranyldiphosphate [7]. The isoprenoids are used for protein prenylation. Simvastatin is one of statins and a secondary metabolite produced by fungi [7]. The acidosis-dependent inhibition of cancer cells by statins was caused by the attenuation of protein geranylgeranylation [8], suggesting that a prenylated protein(s) functions to support cell proliferation at an acidic $\mathrm{pH}$. Unfortunately, such a protein(s) remains to be unidentified.

Immune cells infiltrate various cancer nests [9-13] and suppress cancer growth [13]. The acidification of cancer nests may affect immune cell functions, such as cytokine production. The inductions of human dendritic cell maturation [14] and TNF secretion from macrophages were observed under acidic conditions [15]. Extracellular acidosis stimulated IL- $1 \beta$ secretion by human monocytes without affecting the production of TNF- $\alpha$ [16]. Our group demonstrated that extracellular acidic environments enhanced T-cell signaling induced by TCR stimulation, followed by the increase in phosphorylation of TCR signal proteins [17].
Similar acidic environments were also associated with rheumatoid arthritis. The $\mathrm{pH}$ of articular fluid in the rheumatoid human joint knee was reported to be around 6.6, compared to around 7.3 in normal joints [18]. Other studies also showed the acidification of synovial fluid in the rheumatoid joints [19-21]. Our group demonstrated that synovial cell survival was preferentially inhibited by statins at an acidic $\mathrm{pH}$ [8]. Immune cells are present in the rheumatoid human joint knee [22].

These previous observations revealed the effectiveness of acidosisdependent drugs for chemotherapeutics against cancer cell growth and inflammation. It remains unclear how such drugs affect immune cell functions in acidic, diseased areas. In the present study, we found that simvastatin and manumycin A preferentially suppressed the proliferation and survival of immune cell lines at an acidic $\mathrm{pH}$, and that the statin attenuated the production of TNF- $\alpha$, IL- $1 \beta$, and IL- 8 under acidic conditions.

\section{Materials and Methods}

\section{Cells and reagents}

Human monocytic cell lines THP-1 and Jurkat E6.1 derived from human $\mathrm{T}$ cells were donated by Itsuko Ishii (Chiba University, Japan) and Takashi Saito (RIKEN, Japan), respectively, and cells were cultured at $37^{\circ} \mathrm{C}$ under $5 \% \mathrm{CO}_{2}$ in RPMI-1640 containing $24 \mathrm{mM} \mathrm{NaHCO}_{3}, 10$ $\mu \mathrm{g} / \mathrm{mL}$ gentamycin, $5 \mu \mathrm{g} / \mathrm{mL}$ fungizone, and $10 \%$ fetal bovine serum (FBS).

Simvastatin was purchased from Wako (Osaka, Japan). In the

*Corresponding author: Hiroshi Kobayashi, Graduate School of Pharmaceutical Sciences, Chiba University, 1-8-1, Inohana, Chuo-ku, Chiba 260-8675, Japan, Tel: 81432262892; E-mail: hiroshi@faculty.chiba-u.jp

Received December 20, 2014; Accepted February 13, 2015; Published February 16,2015

Citation: Fukamachi T, Saito H, Kobayashi H (2015) Effect of Simvastatin on Immune Cells under Alkaline and Acidic Conditions. J Cancer Sci Ther 7: 048-054. doi:10.4172/1948-5956.1000324

Copyright: @ 2015 Fukamachi T, et al. This is an open-access article distributed under the terms of the Creative Commons Attribution License, which permits unrestricted use, distribution, and reproduction in any medium, provided the original author and source are credited. 
indicated experiments, the statin was converted to the open ring form before use, as described previously [23]. Manumycin A (Wako) and YM-53601 (Sigma-Aldrich) were purchased. Cell Counting Kit 8 was purchased from Dojindo (Kumamoto, Japan).

\section{Media for cell proliferation and survival assays under different pH conditions}

Media at various $\mathrm{pH}$ values for cell proliferation and survival assays were prepared as follows. To minimize the $\mathrm{pH}$ change during cell culture, $10 \mathrm{mM}$ PIPES [piperazine- $N, N^{\prime}$-bis (2-ethanesulfonic acid)] for acidic media or HEPES [4-(2-hydroxyethyl)-1-piperazineethanesulfonic acid] for alkaline media was added to RPMI-1640 instead of $\mathrm{NaHCO}_{3}$. Medium containing FBS was often contaminated with microbes when the medium $\mathrm{pH}$ was adjusted. Therefore, the medium $\mathrm{pH}$ was first adjusted by the addition of $\mathrm{NaOH}$ to medium without FBS. After sterilization of the medium by filtration, FBS was added. Since the medium $\mathrm{pH}$ was changed by the addition of FBS, the $\mathrm{pH}$ of medium without FBS was adjusted to a lower and higher value than the final $\mathrm{pH}$ in acidic and alkaline media, respectively. For example, when media of $\mathrm{pH} 6.1,6.7$, and 7.5 containing $10 \% \mathrm{FBS}$ were used, the $\mathrm{pH}$ values were adjusted to 5.8, 6.4, and 7.6, respectively, before the addition of FBS. An inhibitor was added after the addition of FBS when indicated.

\section{Inhibitory effect of various inhibitors on cell survival at different $\mathrm{pH}$ values}

Cells were suspended in pH 7.5 RPMI-1640 medium prepared as described above, and $50 \mu \mathrm{L}$ of the cell suspensions was placed in 96-well plates at $7.5 \times 10^{2}$ cells/well. After incubation for 1 day at $37^{\circ} \mathrm{C}$ without a $\mathrm{CO}_{2}$ supply, $100 \mu \mathrm{L}$ of $\mathrm{pH}$ 6.1 RPMI-1640 medium containing the indicated inhibitor was added to the wells. The $\mathrm{pH}$ of the resulting mixture was 6.7. For incubation at $\mathrm{pH} 7.5,100 \mu \mathrm{L}$ of $\mathrm{pH} 7.5 \mathrm{RPMI}-$ 1640 medium containing the indicated inhibitor was added to the wells. Culture plates were put in the box with sterilized water, and then the box was covered with a loose lid to minimize evaporation of the medium. The box was incubated at $37^{\circ} \mathrm{C}$ in an incubator without a $\mathrm{CO}$ supply. Cells were cultured for 5 days without a $\mathrm{CO}_{2}$ supply, and cell survival was determined with Cell Counting Kit 8.

\section{Inhibitory effect of various inhibitors on cell proliferation at acidic $\mathrm{pH}$}

Cells were suspended in RPMI-1640 media of $\mathrm{pH} 6.7$ or 7.5 prepared as described above at $1.4 \times 10^{5}$ cells per $\mathrm{mL}$, and inhibitors indicated were added. Cells were cultured for 4 days without a $\mathrm{CO}_{2}$ supply, and cell proliferation was determined by counting the number of cells not stained with trypan blue before and after incubation.

\section{Real-time RT-PCR}

Total RNA was isolated using TRI reagent (sigma-Aldrich) from cells incubated for 2 days at different $\mathrm{pH}$ values with or without simvastatin, and $1 \mu \mathrm{g}$ of total RNA was subjected to RT reaction. The cDNAs were subjected to real-time RT-PCR using Fast Start Universal SYBR Green Master ROX (Roche) with the ABI7000 system (Applied Biosystems). 18S rRNA was used as a control RNA. Since the amount of ribosomes in mammalian cells is $4 \times 10^{6}$ per cell [24], the amount of mRNA relative to that of $18 \mathrm{~S}$ rRNA gives an approximate copy number of mRNA per cell. The primers used are described in Table 1 . Sequences of TNF- $\alpha$, IL-1 $\beta$, IL-8, and 18S rRNA were quoted from NM_000594.2, NM_000576.2, NM_000584.2, and [25], respectively.

\section{Statistical analysis}

The Student's t-test was utilized in this study.
Inhibition of cell proliferation and survival of THP-1 cells by various inhibitors. (A) The $\mathrm{p}$ values compared with data obtained without simvastatin at both $\mathrm{pH}$ values were calculated. ${ }^{*} \mathrm{p}<0.01$; no mark, $\mathrm{p}<0.01$. (B to $\mathrm{D}$ ) the $\mathrm{p}$ values at $\mathrm{pH} 6.7$ compared with data at $\mathrm{pH}$ 7.5 were calculated. ${ }^{*} \mathrm{p}<0.01$; no mark, $\mathrm{p}>0.01$.

Inhibition of cell survival of Jurkat cells by simvastatin, manumycin A, and YM-53601. The mean values and S.D. obtained from three experiments using different cultures are represented. S.D. less than $10 \%$ is not represented. The $\mathrm{p}$ values at $\mathrm{pH} 6.7$ compared with data at $\mathrm{pH} 7.5$ were calculated. ${ }^{*} \mathrm{p}<0.01$; no mark, $\mathrm{p}>0.01$.

Expression of cytokine genes in THP-1. The mean values and S.D. obtained from three experiments using different cultures are represented. The $\mathrm{p}$ values compared with data obtained without simvastatin at both $\mathrm{pH}$ values were calculated. ${ }^{*} \mathrm{p}<0.01$; no mark, $\mathrm{p}>0.01$. The $\mathrm{p}$ values at $\mathrm{pH} 6.7$ compared with data at $\mathrm{pH} 7.5$ were calculated in the absence of simvastatin. ${ }^{* *} \mathrm{p}<0.01$.

\section{Results}

\section{Inhibition of proliferation and survival at acidic $\mathrm{pH}$}

When cells were cultured under our conditions, the medium $\mathrm{pH}$ decreased and increased continuously in alkaline and acidic media, respectively. After 5 days culture, the medium $\mathrm{pH}$ values were 7.3 and 6.8 when media of $\mathrm{pH} 7.5$ and 6.7 were used, respectively.

Simvastatin at $2 \mu \mathrm{M}$ suppressed the proliferation of human monocyte THP-1 cells only at pH 6.7 (Figure 1A). The effect of simvastatin on cell survival was subsequently examined, and the results showed that $5 \mu \mathrm{M}$ simvastatin markedly reduced THP-1 survival at $\mathrm{pH}$ 6.7, while it had no significant effect on survival at $\mathrm{pH} 7.5$ (Figure 1B). Statins exist in two forms, a lactone form and open ring hydroxy acid form [26]. It was reported that the lactone form is absorbed from the gastrointestinal tract and transformed into the open ring form in vivo [27]. Similar results were obtained with the two forms. The survival decreased with a lower concentration of manumycin A at $\mathrm{pH} 6.7$ than that at $\mathrm{pH} 7.5$ (Figure 1C), whereas the difference in survival between the two $\mathrm{pH}$ conditions was small in cells treated with YM-53601 (Figure 1D). Statins are inhibitors of HMG-CoA reductase (Figure 1E). Manumycin A and YM-53601 inhibit protein prenylation and cholesterol synthesis, respectively (Figure 1E). These results were similar to those obtained with mesothelioma [5] and synovial cells [8]. Similar results were also obtained in Jurkat $\mathrm{T}$ cells derived from human T cells (Figure 2). Protein prenylation has been suggested to be a pathway required for the proliferation and survival of any type of cell under acidic conditions.

\section{Expression of cytokines under acidic conditions}

The effect of simvastatin on the expression of cytokine genes was subsequently examined in THP- 1 cells. Levels of TNF- $\alpha$ and IL- $1 \beta$ produced by immune cells were suggested to have inhibitory effects

\begin{tabular}{|c|c|c|c|}
\hline Gene & & Sequence & Size \\
\hline TNF- $\alpha$ & forward & CCCCAGGGACCTCTCTCTAATC & 98 \\
\hline & reverse & GGTTTGCTACAACATGGGCTACA & \\
\hline IL-1 $\beta$ & forward & GGACAAGCTGAGGAAGATGC & 120 \\
\hline & reverse & TCGTTATCCCATGTGTCGAA & \\
\hline IL-8 & forward & TCTGGCAACCCTAGTCTGCT & 136 \\
\hline & reverse & GCTTCCACATGTCCTCACAA & \\
\hline $18 S$ rRNA & forward & TAGAGTGTTCAAAGCAGGCCC & 81 \\
\hline & reverse & CCAACAAATAGAACCGCGGT & \\
\hline
\end{tabular}

Table 1: Primers used in this study. 

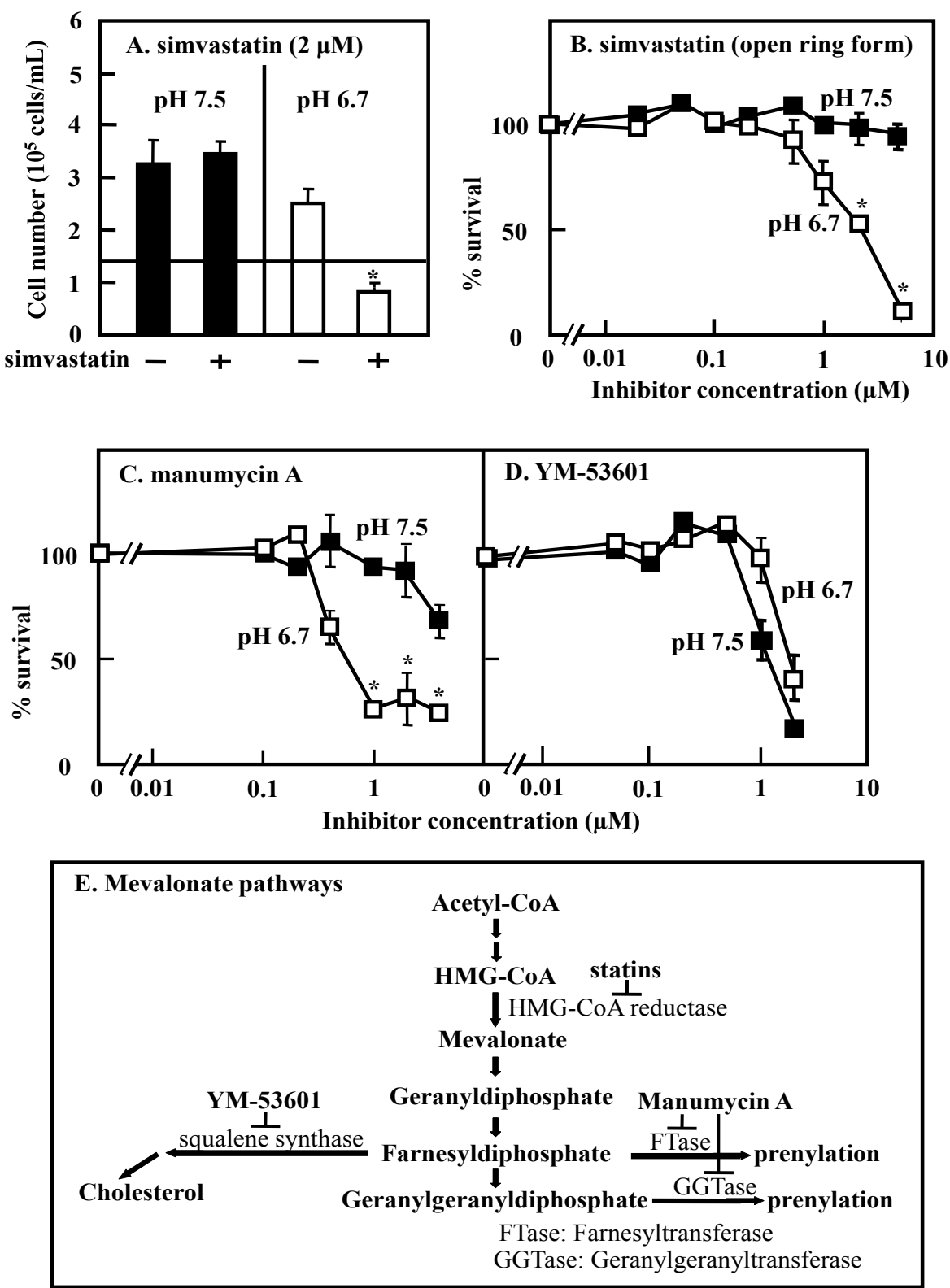

Figure 1: Inhibition of cell proliferation and survival of THP-1 cells by various inhibitors. (A) THP-1 cells were cultured in RPMI-1640 media at pH 6.7 or pH 7.5 for 4 days with simvastatin at the concentrations indicated, and cell numbers were measured as described in Materials and Methods. The dotted line represents the cell number before culture. The mean values and S.D. obtained from two experiments using different cultures are represented. The $\mathrm{p}$ values compared with data obtained without simvastatin at both $\mathrm{pH}$ values were calculated. * $\mathrm{p}<0.01$; no mark, $\mathrm{p}>0.01$. (B) to (D) THP-1 cells were cultured in RPMI-1640 media at $\mathrm{pH} 6.7$ or $\mathrm{pH} 7.5$ for 5 days with the inhibitors indicated, and cytotoxicity was measured as described in Materials and Methods. Absorbance obtained without an inhibitor was taken as $100 \%$. The mean values and S.D. obtained from three experiments using different cultures are represented. S.D. less than $10 \%$ is not represented. The p values at $\mathrm{pH} 6.7$ compared with data at $\mathrm{pH} 7.5$ were calculated. * $\mathrm{p}<0.01$; no mark, $\mathrm{p}>0.01$. (E) Mevalonate pathways.

on tumor progression $[28,29]$. TNF- $\alpha$ was up-regulated 10 -fold under acidic conditions compared with that at $\mathrm{pH} 7.5$ in THP-1 cells, and the increased gene expression was significantly suppressed by simvastatin at $\mathrm{pH} 6.7$ (Figures $3 \mathrm{~A}$ and $\mathrm{B}$ ). The expression of IL-1 $\beta$ was enhanced at an acidic $\mathrm{pH}$, and this elevated expression was reduced by simvastatin in THP-1 cells (Figures 3C and D). Similar effects of the extracellular $\mathrm{pH}$ and simvastatin on the expression of IL- 8 were observed (Figures $3 \mathrm{E}$ and $\mathrm{F}$ ). These results suggest that expression of the inflammatory cytokines TNF- $\alpha$, IL-1 $\beta$, and IL- 8 was enhanced in cancer nests associated with extracellular acidosis, and that the expression was inhibited by statins. The expression of IL- 8 at an acidic $\mathrm{pH}$ was reported in tumor cells $[30,31]$. Since the mRNA levels of IL- $1 \beta$ and IL- 8 were very low compared with that of TNF- $\alpha$ (Figures $3 \mathrm{~B}, \mathrm{D}$, and $\mathrm{F}$ ), the expressions of IL- $1 \beta$ and IL-8 may be less significant physiologically.

Simvastatin increased the expression of TNF- $\alpha$, IL- $1 \beta$, and IL-8 at 5,2 , and $2 \mu \mathrm{M}$, respectively, in alkaline medium (Figure 3), while this drug inhibited the expression in a dose-dependent manner at an acidic $\mathrm{pH}$. It remains unclear why simvastatin increases the expression of these cytokines. 

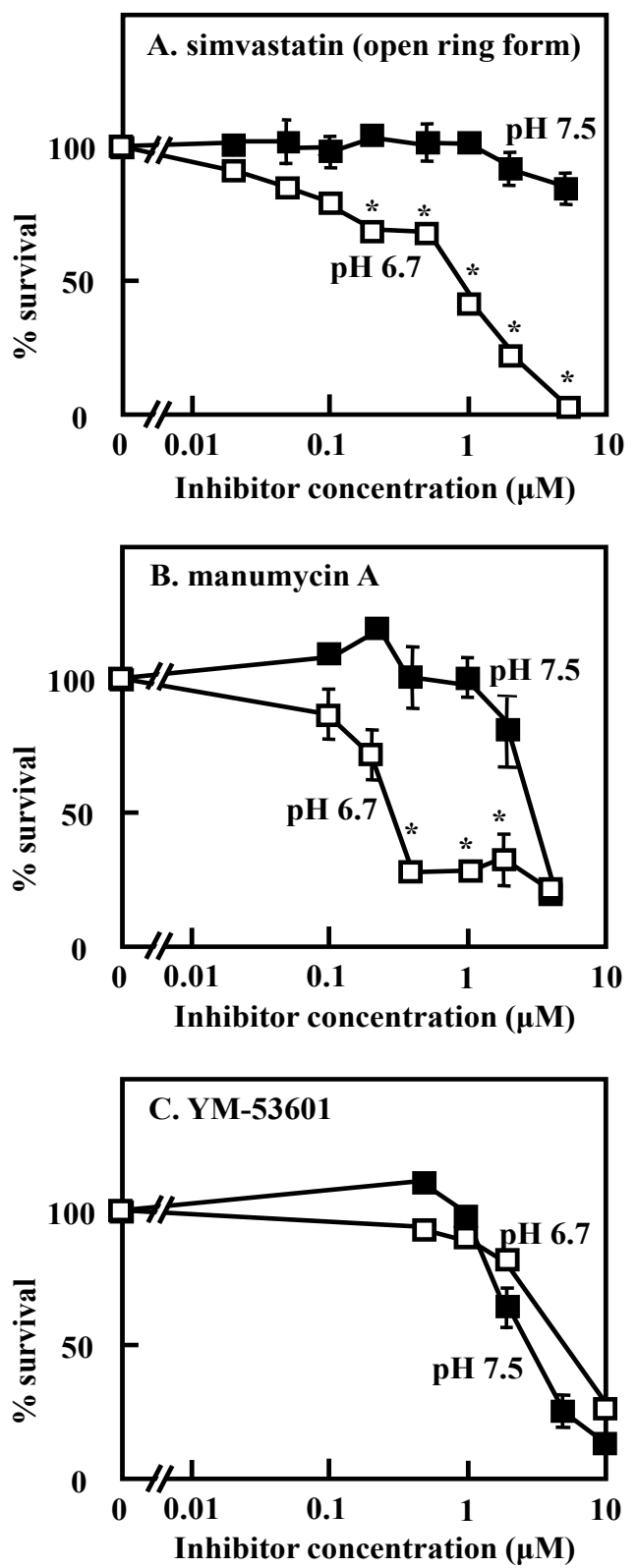

Figure 2: Inhibition of cell survival of Jurkat cells by simvastatin, manumycin $\mathrm{A}$, and YM-53601. Jurkat cells were cultured in RPMI-1640 media at $\mathrm{pH}$ 7.5 or 6.7 for 5 days with simvastatin, manumycin A, or YM-53601 at the concentrations indicated, and cell survival was measured as described in the legend of Figure 1B. The mean values and S.D. obtained from three experiments using different cultures are represented. S.D. less than $10 \%$ is not represented. The $\mathrm{p}$ values at $\mathrm{pH} 6.7$ compared with data at $\mathrm{pH} 7.5$ were calculated. ${ }^{*} p<0.01$; no mark, $p>0.01$.

\section{Discussion}

Statins were reported to inhibit the proliferation and survival of cancer [5] and synovial [8] cells under acidic conditions. The acidosisdependent inhibition by simvastatin was observed in immune cells in the present study. Cancer nests and inflammatory loci were acidified by the limitation of oxygen [3,18-21]. It is therefore suggested that statins have a marked effect on any type of cell under acidic conditions which are close to those in cancer nests. When the box was sealed, cells were damaged after 4 to 5 days of culture, suggesting that oxygen is required for proliferation at an acidic $\mathrm{pH}$. It was essential for preventing the cell damage to take off the lid of the box for a while every two days. The oxygen level might decrease during culture in the box.

The suppressive effect of statins on T cells has already been reported. Atorvastatin inhibits T-cell activation and proliferation [32]. In their report, the inhibition of Jurkat cell proliferation by $10 \mu \mathrm{M}$ atorvastatin was approximately $60 \%$, being close to our results obtained with simvastatin at $\mathrm{pH} 7.5$ (Figure $2 \mathrm{~A}$ ). The association of signaling proteins including Lck to membrane rafts was reported to be inhibited by statins with decreasing cholesterol synthesis [32]. In addition to the effect on lipid rafts, the inhibition of protein geranylgeranylation by statins was found to be critical for T-cell functioning [33]. The prenylation of small $G$ proteins was inhibited by statins, and the inhibition affected several intracellular functions including cell proliferation [34]. These data may support the mechanism in which the effect of statins on cell proliferation and survival is due to the attenuation of a geranylgeranylated protein(s). This mechanism would be more important under acidic conditions because sensitivity to statins was enhanced at a low $\mathrm{pH}$ and manumycin A preferentially suppressed cell survival at a low $\mathrm{pH}$ (Figure 1). G protein-coupled receptor on T-cell membranes encoded by T-cell death-associated gene 8 (TDAG8) was assumed to be a pH sensor to regulate intracellular cAMP under acidic environments [35]. Ras was reported to be more active at a low $\mathrm{pH}$ and to activate cAMP-dependent kinase (PKA) [36], suggesting that PKA signaling has an important role in cellular survival at an acidic $\mathrm{pH}$.

Our present results demonstrated that TNF- $\alpha$ was expressed at a higher level at an acidic $\mathrm{pH}$ compared with that at an alkaline $\mathrm{pH}$ in THP-1. Simvastatin prevented TNF- $\alpha$-induced NF- $\kappa B$ activation, which ultimately results in the secretion of pro-inflammatory cytokines [37]. Our results showed the significant inhibition of TNF- $a$ expression by simvastatin at an acidic $\mathrm{pH}$. Simvastatin also significantly inhibited the production of IL- $1 \beta$ and IL-8 in THP-1 (Figure 3 ). Some statins were reported to induce apoptosis via caspase-3 activation [38], but such activation was not observed in the present study (data not shown).

The protein synthesis may be dependent on a copy number of mRNA, because the binding chance of mRNA to ribosomes declines as the decrease in the copy number. The copy number of mRNA was calculated based on the content of ribosomes per cell in this study. The content is written in the textbook [24], and this number was used. The content was also calculated based on the published data [39], and the same result was obtained. No data concerning the content of ribosomes in cells cultured at an acidic $\mathrm{pH}$ has been reported. The content of $18 \mathrm{~S}$ RNA was measured using PCR in this study, and Ct values were almost the same in all cells cultured in this study (data not shown). We, therefore, assumed that the content of ribosomal RNA is constant even if the culture $\mathrm{pH}$ is different.

TCR stimulation did not increase cytokine expression at an acidic $\mathrm{pH}$ in Jurkat cells [40] or human peripheral primary $\mathrm{T}$ cells (unpublished observation). The mRNA levels of interleukins and TNF- $a$ were less than 100 copies per cell except IL-10, while the mRNA level of GAPDH was $8 \times 10^{5}$ copies per cell in Jurkat cells [40]. Thus, the expression of these cytokines might be less significant, and the effect of simvastatin on the expression of cytokines was not examined in Jurkat cells in this study.

Our present data showing that cytokine production was inhibited by statin treatment under acidic conditions do not seem to be of merit for cancer therapy. In contrast to an acidic $\mathrm{pH}$, treatment with acidosis-dependent drugs was less effective on immune cells at an 

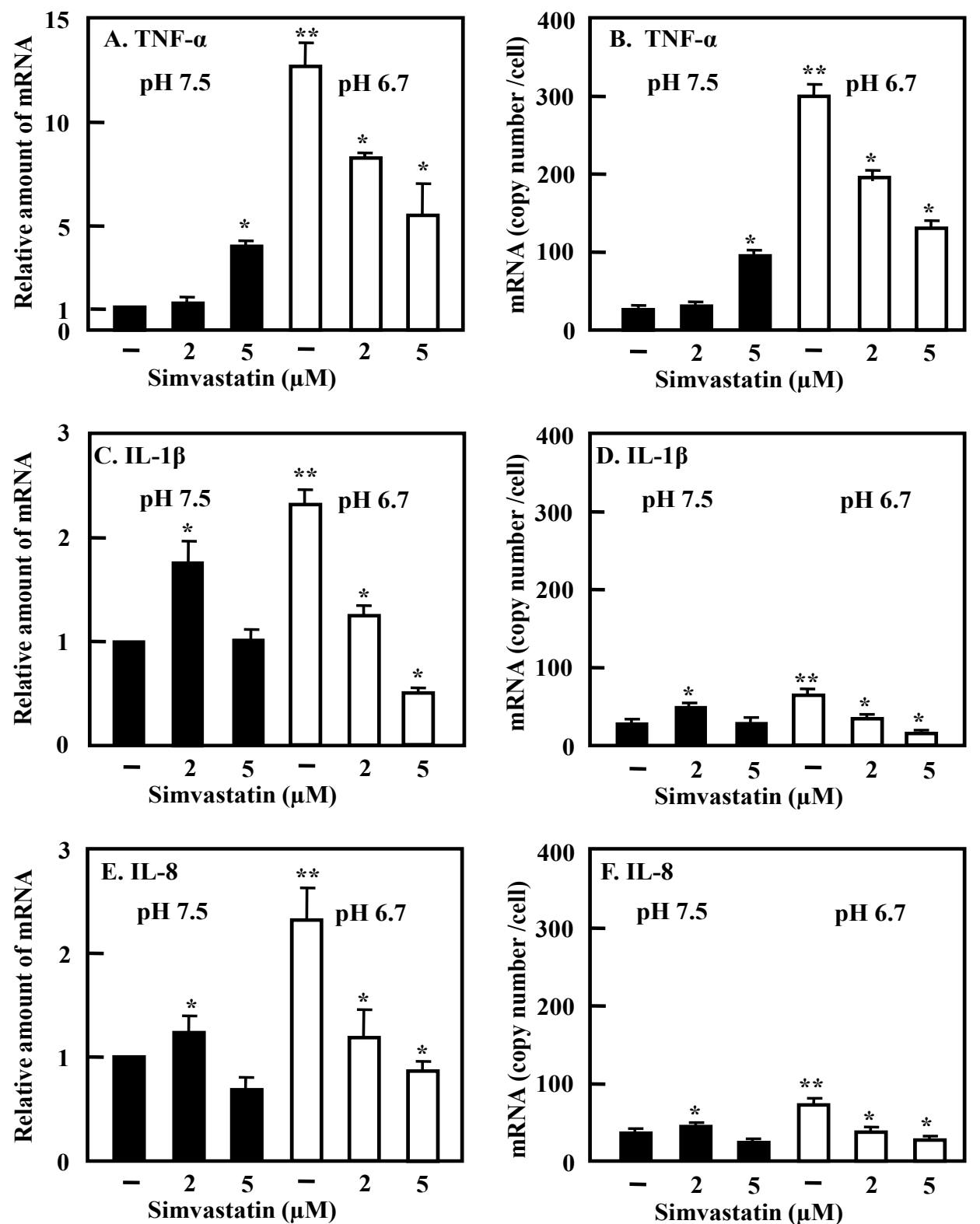

Figure 3: Expression of cytokine genes in THP-1. After THP-1 cells had been cultured in RPMI-1640 media at pH 7.5 or 6.7 for 2 days with simvastatin at the concentrations indicated, the amounts of indicated mRNA were measured as described in Materials and Methods. The left column: Relative increases in mRNA levels of TNF- $\alpha(A), I L-1 \beta(C)$, and IL-8 $(E)$ are represented. The right column: Copy numbers of mRNA per cell of TNF- $\alpha(B)$, IL-1 $\beta(D)$, and IL- $8(F)$ are represented. The mean values and S.D. obtained from three experiments using different cultures are represented. The $p$ values compared with data obtained without simvastatin at both $\mathrm{pH}$ values were calculated. ${ }^{*} \mathrm{p}<0.01$; no mark, $\mathrm{p}>0.01$. The $\mathrm{p}$ values at $\mathrm{pH} 6.7$ compared with data at $\mathrm{pH} 7.5$ were calculated in the absence of simvastatin. ${ }^{* *} p<0.01$.

alkaline $\mathrm{pH}$ that is close to the $\mathrm{pH}$ of normal tissues including blood, suggesting that immune systems could be maintained more actively in the body when acidosis-dependent anti-cancer drugs are used. Statins are now prescribed as drugs to decrease the blood level of cholesterol, and damage of the immune system has not be reported to date in hyperlipidemia patients treated with them. Stains were reported to increase incident diabetes, but the adjusted hazard ratio was 1.04 to 1.17 [41]. The risk of a major cardiovascular event was less than $1 \%$ in patients treated with statins [42]. Chemotherapy combined with immunotherapy is now being developed. It may become possible to create immune cells in which cytokine production is resistant to statins.
It was shown that the expression of many genes was affected by environmental $\mathrm{pH}$ [43]. Some acidosis-dependent genes were shown to be expressed at a higher level in specimens from cancer patients [44]. The present study demonstrated that the efficacy of some medicines increases under acidic conditions. These data suggest the significance of measuring $\mathrm{pH}$ levels inside human body and the $\mathrm{pH}$ change of diseased areas for our improved understanding of therapy and diagnosis.

In conclusion, simvastatin was shown to be less effective at a slightly alkaline $\mathrm{pH}$, being close to that of blood and normal tissues, although this drug exhibits cytotoxicity against immune cells in an acidic medium. Acidosis-dependent drugs such as statins can be 
argued to have weak side effects on the immune system, as shown in the present study. Impairment of the immune system is one of the serious side effects of anti-cancer drugs used commonly now. Our results lead us to anticipate that the screening of chemicals exhibiting high-level cytotoxicity in acidic medium will promote the development of new medicines for chemotherapeutics against cancer with reduced side effects.

\section{Acknowledgements}

We thank Kenta Hatatani and Chie Maruyama for their contribution to part of this study. This work was supported by Special Funds for Education and Research (Development of SPECT Probes for Pharmaceutical Innovation) from the Ministry of Education, Culture, Sports, Science, and Technology of Japan.

\section{References}

1. Swenson ER (2001) Metabolic acidosis. Respir Care 46: 342-353.

2. Feldman JL, Mitchell GS, Nattie EE (2003) Breathing: rhythmicity, plasticity, chemosensitivity. Annu Rev Neurosci 26: 239-266.

3. Simmen HP, Blaser J (1993) Analysis of $\mathrm{pH}$ and $\mathrm{pO}_{2}$ in abscesses, peritoneal fluid, and drainage fluid in the presence or absence of bacterial infection during and after abdominal surgery. Am J Surg 166: 24-27.

4. Warburg O (1956) On the origin of cancer cells. Science 123: 309-314.

5. Fukamachi T, Chiba Y, Wang X, Saito H, Tagawa M, et al. (2010) Tumor specific low $\mathrm{pH}$ environments enhance the cytotoxicity of lovastatin and cantharidin. Cancer Lett 297: 182-189.

6. Fukamachi T, Saito H, Tagawa M, Kobayashi H (2012) The impact of extracellular low $\mathrm{pH}$ on the anti-tumor efficacy against mesothelioma. In Mesotheliomas - Synonyms and Definition, Epidemiology, Etiology, Pathogenesis, Cyto-Histopathological Features, Clinic, Diagnosis, Treatment, Prognosis. (ed. Zubritsky A). InTech (Rijeka, Croatia): 187-210.

7. Fuchs D, Berges C, Opelz G, Daniel V, Naujokat C (2008) HMG-CoA reductase inhibitor simvastatin overcomes bortezomib-induced apoptosis resistance by disrupting a geranylgeranyl pyrophosphate-dependent survival pathway. Biochem Biophys Res Commun 374: 309-314.

8. Fukamachi T, Wang X, Mochizuki Y, Maruyama C, Saito H, et al. (2013) Acidic environments enhance the inhibitory effect of statins on proliferation of synovial cells. Int Immunopharmacol 17: 148-153.

9. Oshikiri T, Miyamoto M, Shichinohe T, Suzuoki M, Hiraoka K, et al. (2003) Prognostic value of intratumoral $\mathrm{CD} 8^{+} \mathrm{T}$ lymphocyte in extrahepatic bile duct carcinoma as essential immune response. J Surg Oncol 84: 224-228.

10. Nakakubo Y, Miyamoto M, Cho Y, Hida Y, Oshikiri T, et al. (2003) Clinical significance of immune cell infiltration within gallbladder cancer. $\mathrm{Br} \mathrm{J}$ Cancer 89: $1736-1742$

11. Zhang L, Conejo-Garcia JR, Katsaros D, Gimotty PA, Massobrio M, et al. (2003) Intratumoral T cells, recurrence, and survival in epithelial ovarian cancer. $\mathrm{N}$ Engl J Med 348: 203-213.

12. Fukunaga A, Miyamoto M, Cho Y, Murakami S, Kawarada Y, et al. (2004) CD8 tumor-infiltrating lymphocytes together with $\mathrm{CD}^{+}$tumor-infiltrating lymphocytes and dendritic cells improve the prognosis of patients with pancreatic adenocarcinoma. Pancreas 28: e26-31.

13. Kawai O, Ishii G, Kubota K, Murata Y, Naito Y, et al. (2008) Predominant infiltration of macrophages and $\mathrm{CD}^{+}{ }^{+} \mathrm{T}$ Cells in cancer nests is a significant predictor of survival in stage IV nonsmall cell lung cancer. Cancer 113: 13871395.

14. Martínez D, Vermeulen M, von Euw E, Sabatté J, Maggíni J, et al. (2007) Extracellular acidosis triggers the maturation of human dendritic cells and the production of IL-12. J Immunol 179: 1950-1959.

15. Jensen JC, Buresh C, Norton JA (1990) Lactic acidosis increases tumor necrosis factor secretion and transcription in vitro. J Surg Res 49: 350-353.

16. Jancic CC, Cabrini M, Gabelloni ML, Rodríguez Rodrigues C, Salamone G, et al. (2012) Low extracellular $\mathrm{pH}$ stimulates the production of IL-1 $\beta$ by human monocytes. Cytokine 57: 258-268.

17. Hirata S, Fukamachi T, Sakano H, Tarora A, Saito H, et al. (2008) Extracellular acidic environments induce phosphorylation of ZAP-70 in Jurkat T cells. Immunol Lett 115: 105-109.
18. Goldie I, Nachemson A (1969) Synovial pH in rheumatoid knee-joints. I. The effect of synovectomy. Acta Orthop Scand 40: 634-641.

19. Ward TT, Steigbigel RT (1978) Acidosis of synovial fluid correlates with synovial fluid leukocytosis. Am J Med 64: 933-936.

20. Geborek P, Saxne T, Pettersson H, Wollheim FA (1989) Synovial fluid acidosis correlates with radiological joint destruction in rheumatoid arthritis knee joints. J Rheumatol 16: 468-472.

21. Andersson SE, Lexmüller K, Johansson A, Ekström GM (1999) Tissue and intracellular $\mathrm{pH}$ in normal periarticular soft tissue and during different phases of antigen induced arthritis in the rat. J Rheumatol 26: 2018-2024.

22. Kinne RW, Stuhlmüller B, Burmester GR (2007) Cells of the synovium in rheumatoid arthritis. Macrophages. Arthritis Res Ther 9: 224.

23. Liu L, Moesner P, Kovach NL, Bailey R, Hamilton AD, et al. (1999) Integrindependent leukocyte adhesion involves geranylgeranylated protein(s). J Bio Chem 274: 33334-33340.

24. Darnel J, Lodish H, Baltimore D (1986) Molecular Cell Biology. Scientific American Books Inc, New York, pp-137.

25. Matsumoto T, Marusawa H, Endo $Y$, Ueda $Y$, Matsumoto $Y$, et al. (2006) Expression of APOBEC2 is transcriptionally regulated by NF-KB in human hepatocytes. FEBS Lett 580: 731-735.

26. Yang DJ, Hwang LS (2006) Study on the conversion of three natural statins from lactone forms to their corresponding hydroxy acid forms and their determination in Pu-Erh tea. J Chromatogr A 1119: 277-284.

27. Ertürk S, Onal A, Müge Cetin S (2003) Analytical methods for the quantitative determination of 3-hydroxy-3-methylglutaryl coenzyme $A$ reductase inhibitors in biological samples. J Chromatogr B 793: 193-205.

28. Saito H, Ando S, Morishita N, Lee KM, Dator D, et al. (2014) A combined lymphokine-activated killer (LAK) cell immunotherapy and adenovirus-p53 gene therapy for head and neck squamous cell carcinoma. Anticancer Res 34: 3365-3370.

29. Ramello MC, Tosello Boari J, Canale FP, Mena HA, Negrotto S, et al. (2014) Tumor-induced senescent $T$ cells promote the secretion of pro-inflammatory cytokines and angiogenic factors by human monocytes/macrophages through a mechanism that involves Tim-3 and CD40L. Cell Death Dis 5: e1507.

30. Xu L, Fidler IJ (2000) Acidic pH-induced elevation in interleukin 8 expression by human ovarian carcinoma cells. Cancer Res 60: 4610-4616.

31. Chen JL, Merl D, Peterson CW, Wu J, Liu PY, et al. (2010) Lactic acidosis triggers starvation response with paradoxical induction of TXNIP through MondoA. PLoS Genet 6: e1001093.

32. Blank N, Schiller M, Krienke S, Busse F, Schätz B, et al. (2007) Atorvastatin inhibits $T$ cell activation through 3-hydroxy-3-methylglutaryl coenzyme $A$ reductase without decreasing cholesterol synthesis. J Immunol 179: 36133621.

33. Waiczies S, Bendix I, Prozorovski T, Ratner M, Nazarenko I, et al. (2007) Geranylgeranylation but not GTP loading determines rho migratory function in T cells. J Immunol 179: 6024-6032.

34. Girgert R, Marini P, Janessa A, Bruchelt G, Treuner J, et al. (1994) Inhibition of the membrane localization of p21 ras proteins by lovastatin in tumor cells possessing a mutated $\mathrm{N}$-ras gene. Oncology 51: 320-322.

35. Ishii S, Kihara Y, Shimizu T (2005) Identification of $T$ cell death-associated gene 8 (TDAG8) as a novel acid sensing G-protein-coupled receptor. J Biol Chem 280: 9083-9087.

36. Haworth RS, Dashnyam S, Avkiran M (2006) Ras triggers acidosis-induced activation of the extracellular-signal-regulated kinase pathway in cardiac myocytes. Biochem J 399: 493-501.

37. Xu H, Liu P, Liang L, Danesh FR, Yang X, et al. (2006) RhoA-mediated, tumor necrosis factor $\alpha$-induced activation of NF-KB in rheumatoid synoviocytes: inhibitory effect of simvastatin. Arthritis Rheum 54: 3441-3451.

38. Nagashima T, Okazaki H, Yudoh K, Matsuno H, Minota S (2006) Apoptosis of rheumatoid synovial cells by statins through the blocking of protein geranylgeranylation: a potential therapeutic approach to rheumatoid arthritis. Arthritis Rheum 54: 579-586.

39. Watanabe S, Kusama-Eguchi K, Kobayashi H, Igarashi K (1991) Estimation of 
Citation: Fukamachi T, Saito H, Kobayashi H (2015) Effect of Simvastatin on Immune Cells under Alkaline and Acidic Conditions. J Cancer Sci Ther 7: 048-054. doi:10.4172/1948-5956.1000324

polyamine binding to macromolecules and ATP in bovine lymphocytes and rat liver. J Biol Chem 266: 20803-20809.

40. Wang X, Hatatani K, Sun Y, Fukamachi T, Saito H, et al. (2012) TCR signaling via ZAP-70 induced by CD3 stimulation is more active under acidic conditions. J Cell Sci Ther S15: 002.

41. Carter AA, Gomes T, Camacho X, Juurlink DN, Shah BR, et al. (2013) Risk of incident diabetes among patients treated with statins: population based study. BMJ 346: f2610.

42. Taylor F, Huffman MD, Macedo AF, Moore TH, Burke M, et al. (2013) Statins for the primary prevention of cardiovascular disease. Cochrane Database Syst Rev 1:CD004816.

43. Fukamachi T, Ikeda S, Wang X, Saito H, Tagawa M, et al. (2013) Gene Expressions for Signal Transduction under Acidic Conditions. Genes (Basel) 4: $65-85$.

44. Fukamachi T, Ikeda S, Saito H, Tagawa M, Kobayashi H (2014) Expression of acidosis-dependent genes in human cancer nests. Mol Clin Oncol 2: 11601166. 